\title{
Transnational Immigration and Education: A Case Study of an Ethiopian Immigrant High School Student
}

\author{
Afra Ahmed Hersi \\ Department of Teacher Education, Loyola University Maryland, Baltimore, USA \\ Email: ahersi@loyola.edu
}

Received November $9^{\text {th }}, 2011$; revised December $11^{\text {th }}$, 2011; accepted December $25^{\text {th }}, 2011$

\begin{abstract}
There is a need to develop greater understanding of the transnational nature of immigrant students' experiences. This article explores the complex factors, both individual and social, that contribute to the resiliency and academic achievement of an Ethiopian student enrolled in a small high school in the United States. The study examines the student's pre-and post-immigration experiences with a particular focus on family and school context. The goal was to understand the factors that contributed to his resiliency and to identify practical strategies for supporting the academic and social success of immigrant students.
\end{abstract}

Keywords: Immigrant Education; Transnational Family Context; School Context; Resiliency

\section{Introduction}

According to the most recent US Census (2010), in 200936.7 million residents (12\%) were foreign-born, and another 33 million (11\%) were native-born with at least one foreign-born parent, making one in five people either first- or second-generation U.S. residents. Unlike immigrants during the early to midtwentieth century, who came primarily from Europe and Canada (Portes \& Rumbaut, 2001; Schmidley, 2001), this recent wave of immigration is much more diverse, with over half of the immigrants originating from Latin America, Asia, the Caribbean Islands, and Africa (Elmelech, McCaskie, Lennon, \& Lu, 2002). Since 1965, Latin America, Asia, Africa, and the Caribbean region have accounted for $85 \%$ of all immigration to the United States (Reimers, 2005) ${ }^{1}$. Recent African immigrants are adding to this increasing diversity in the United States. Although the African foreign-born population is small, it is a rapidly growing segment of the U.S. population. Between the 1990 and 2000 Census, the African immigrant population more than doubled, growing from approximately 364,000 in 1990 to 881,000 in 2000 (Kamaya, 1996; Reimers, 2005; Rong \& Brown, 2002). By 2005, approximately 2.5 million US immigrants were from sub-Saharan Africa (US Census Community Survey, 2006). Four countries (Nigeria, Ghana, Somalia, and Ethiopia) accounted for approximately $40 \%$ of all African immigration to the United States (Arthur, 2000).

Migration scholars (Glick Schiller, 1997; Portes \& Rumbaut, 2001) have documented the ways in which technological innovations, globalization, and ease of transportation have altered our understanding of migration. Today’s immigrants maintain transnational ties, building social networks that "link together their country of origin and their country of settlement” (Kivisto,

\footnotetext{
${ }^{1}$ In 1965, Congress passed the Hart-Cellar Immigration Reform Act, a sweeping reform of the nation's immigration policy. This act abolished the restrictive national quota system that had governed US immigration policy since 1924 (Reimers, 2005). The Hart-Cellar Act replaced a flagrantly racist system that favored immigration from Europe while sharply restricting the number of immigrants from Asia, Africa, and the Caribbean (Reimers).

${ }^{2}$ The names of individuals and schools in this study have been changed to protect their identity.
}

2001: p. 552). Therefore, teachers and other educators need to understand the transnational nature of immigrant students' experiences. To that end, my goal in this article is to examine the immigration and educational experiences of one such student, Warkana, enrolled in a US high school designed specifically for immigrant students in Massachusetts ${ }^{2}$. My purpose is to uncover the complex factors that contributed to Warkana's resiliency and academic achievement.

For the purposes of this study, resilience is understood as the capacity of youth to thrive physically, psychologically, and academically despite adversities and exposure to stress (Perez, Espinoza, Ramos, Coronado, \& Cortes, 2009; Wang, Haertel, \& Walberg, 1993; Waxman, Gray, \& Padron, 2003). Academic achievement was determined by a number of factors, including grade point average, teacher recommendations, high school graduation, and acceptance to college. Exploring Warkana’s immigration experiences, I provide a brief overview of relevant literature on immigration and education and on the history of Ethiopia and Ethiopian immigration to the United States. Next I explore Warkana's pre- and post-immigration and experiences, with particular focus on his school and family contexts. My goal was to understand the factors that contributed to his resiliency and to identify practical strategies for supporting the academic and social success of students like Warkana.

\section{Immigration and Education}

Immigrants do not start on an even playing field-government policies, media portrayals, society's reception of immigrants, and the presence and size of their ethnic community have a great impact on their success in adapting to life in the United States. Portes and Rumbaut (2001) and others have documented a number of instances in which immigrants engage in selective acculturation, in which they shield themselves against poverty and economic pressures by retaining the community and family networks that provide social capital and cultural values and traditions (Gibson, 1988; Lee \& Bean, 2004; Portes \& Zhou, 1993; Rong \& Brown, 2002). For example, Gibson's (1988) two-year ethnographic study of the experiences of Punjabi Sikh immi- 
grants in a small farming community in California found that the high school-aged students often outperformed both majority and long-established minority students. The Punjabi students did well in school despite significant cultural conflicts between their home and school life, little direct parental involvement, prejudice, language proficiency problems, and a depressed socioeconomic status. Gibson explains that Punjabi parents encouraged their children to give up specific cultural practices, thereby accommodating the dominant group while maintaining their cultural identity. Through such adaptive responses, Punjabi students' social networks of community and family helped them to maintain a positive identity and resiliency.

Other research on immigrant students' acculturation also suggests that contextual factors such as family and school in the host country play a significant role in the adjustment and adaptation of immigrant students (Fonor, 2005; Lee \& Bean, 2004 Portes \& Zhou, 1993; Reyes \& Jason, 1993; Suarez-Orozco \& Suarez-Orozco, 2001). Researchers have often noted that the stress associated with immigration continues to affect individuals and families as they adjust to new family situations and relationships (Suárez-Orozco, Todorova, \& Louie, 2005). For many immigrant students separated from family members, migration represents what Boss (1999) refers to as "ambiguous loss" when a beloved family member is physically absent but psychologycally present. Similarly, Falicov (2005), working with Latino immigrant families, noted that "migration brings with it losses of all kinds. Gone are family members and friends who stay behind; gone is the native language, customs, and rituals; gone is the land itself" (p. 197). Often the stress and homesickness that immigrant families experience leads to another type of ambiguous loss-situations where family members are physically present but psychologically absent (Foner, 2005). Although migration and family contexts can be major sources of stress for immigrant students, family contexts and co-ethnic social networks have also been found to be significant factors in resiliency (Foner, 2005; Portes \& Rumbaut, 2001; Suárez-Orozco, Todorova, \& Louie, 2005).

\section{Ethiopian Immigration to the United States}

The Ethiopian immigrant population in the United States, estimated to be between 250,000 and 350,000, is ethnically and religiously diverse. Similar to that of other African immigrants, the migration pattern of Ethiopians in the United States occurred in four waves (Arnold, 2005; Harris, 1993). The first wave (1960-1974) consisted mostly of elites who came to the United States to attend college or to work (Getahun, 2007). The emergence of the Derg regime was followed by a sharp increase in Ethiopian immigration to the United States. This second wave of Ethiopian migration (1975-1991), though still relatively privileged, was in direct response to the persecution and human rights violations carried out by the Derg regime and its eventual collapse in 1991 (Getahun \& Matteo, 2007). The third wave of migration, which took place in the mid-1990s to 2000s, was composed of individuals fleeing Ethiopia because of ethnic violence and political unrest. According to Matteo (2007), the most recent wave, the fourth, was made up of individuals immigrating to the United States under family unification policies. Ethiopian individuals who had arrived as refugees in the 1990s and earlier, sponsored family members to come the United States. The case study student, Warkana's immigration journey to the United States is situated in this most recent wave of Ethiopian immigration.
Immigration in the $21^{\text {st }}$ century is profoundly transnational. Similar to other immigrants in the United States, Ethiopians remain involved in their country of origin. These transnational ties include financial remittances (sending money to relatives and direct investment in business) and frequent travel to Ethiopia. Remittances, totaling over $\$ 400$ million from the Ethiopia diaspora, mainly the Ethiopian community in the United States, account for the single largest source of foreign exchange in Ethiopia (Getahun, 2007). Family and kinship networks, particularly to children and parents left behind, are an important motivation for maintaining these transnational ties.

As is common for transnational communities, immigrants also build social networks in their new country (Fonor, 2005). Once in the United States, Ethiopian immigrants established community development associations, churches, business, and other institutions. Many of these organizations and institutions organize around ethnic lines, thus reproducing some the ethnic tensions in Ethiopia itself (Getahun, 2007). Wakana, the student featured in this article, settled in a Trigrian Ethiopian community in Massachusetts.

\section{Warkana's Journey}

Immigration is a complex process that affects and transforms every aspect of an individual's life. This was certainly true for Warkana, a soft-spoken young man who was devoted to his mother and his 13-year-old brother. Warkana was born in Tigray, Ethiopia, a very small town. According to Warkana, "We live[d] close to Eritrean border [and] far from everything”. His village was mostly quiet in recent years, but Warkana did recall witnessing Ethiopian soldiers on their way to the border wars with Ethiopia as a child. "I remember, when I was small, there were many trucks and soldiers. My family told me, we have war with Eritrea.” Although he did not recall any violence or conflict in or near his village, Warkana did share that his uncle was in the Ethiopian army and fought in the war with Eritrea.

\section{Migration History}

For most of his life, Warkana lived with his maternal grandparents. His parents divorced when he was very young and his mother gained sole custody, which was unusual in Ethiopia. When Warkana was a small child, his mother immigrated to the United States. After nearly 14 years in the US, his mother sponsored his immigration to the United States. To facilitate the paperwork, Warkana had to move to Addis Ababa, the capital of Ethiopia. He lived in Addas Ababa for almost three years, awaiting his legal paper work. This paperwork included a new U.S. requirement to submit a DNA test, documenting the biological relationship between Warkana and his mother. Family reunification policies have actually become quite complex and expensive for individuals. His mother had save money and coordinated the paperwork, both here in the United States and in Ethiopia. Although moving to Addas Ababa removed him from his maternal grandmother, the access to the capital made his legal paperwork easier to handle. During his time in Addas Ababa, Warkana had lived with his father's family. Warkana did not have a relationship with his father-indeed; his paternal grandmother took responsibility for him at this time. Besides waiting for his immigration paperwork, Warkana was able to go to high school during his three years in Addas Ababa.

Warkana was 17 years old when he left Ethiopia in 2005. He traveled by himself, making the 18-hour trip from Addis Ababa 
to Washington, DC with transfer points in Italy. His mother met him in Washington, DC, and they drove to Massachusetts. Before coming to the United States, Wankana had "thought everything [was] like free, all the schools, everything." He was amazed by the freedom enjoyed by people living in America. As he poignantly explained, "Everybody in this country is, you know, I don't know how to say it ... is like nobody is afraid of anything ... like they talk freely, do whatever they want. Here you can be like anything." Despite the freedom and opportunity he found in his new home, the most important thing for Warkana was reuniting with his family: "The thing that I want is to live with my family. That's all.”

For immigrant adolescents like Warkana, migration experiences reshape their lives as the familiar ways of relating to others dramatically change (Suárez-Orozco \& Suárez-Orozco, 2001). Despite these transitions and their associated stressors, Warkana's migration history reveals factors that appear to have contributed to his resilience. First, Warkana obtained legal documentation through US immigration policies that promoted family reunification. As a result, he has access to opportunities and resources (e.g., work permits, high school transcripts, access to college, and student financial aid) not available to undocumented immigrants. Second, Warkana migrated to join family members who were already part of an established co-ethnic community, thus linking them to networks of social support. It is through these social support networks that Warkana's mother learned about the new high school for immigrant students in which he enrolled. Warkana's migration story is consistent with research on immigrant acculturation that shows that immigrants who are able to benefit from favorable government policies gain social capital and are much more likely to successfully adapt to life in the United States (Lee \& Bean, 2004; Portes \& Rumbaut, 2001; Suárez-Orozco \& Suárez-Orozco, 2001).

\section{Family Contexts}

In the Ethiopian context, family refers to both the immediate family (parents, siblings) and the extended family (grandparents, uncles, aunts, cousins). Like many other immigrant children, Warkana grew up in a transnational family context. Transnational families are characterized by the separation and reunification of different family members over time (Suárez-Orozco, Bang, \& Kim, 2011). In transnational families, family members have separate living arrangements in two or more countries but maintain close links with relatives in their home counties (Foner, 2005). This practice of "'familyhood' even across the national boarders" (Bryceson \& Vuorela, 2002: p. 3) has been well documented by researchers (Dreby, 2009; Foner, 2005; Suárez-Orozco, Todorava, \& Louie, 2002) but has remained largely unexamined in the educational literature.

Children growing up in transnational families experience prolonged family separations and periods of family reunification. Warkana's family context was very much framed by this transnational context. Despite the fact his mother lived and worked in America, Warkana developed a close relationship with her based on weekly phone calls, two trips back to Ethiopia, and financial support through remittances. His mother also encouraged him to emigrate, stressing that if he came to the United States and studied hard, he could get a college education. "My mom always say, 'I want you to come here and go to school.' Study hard and be good student.”
Even though Warkana felt supported by his mother, it was clear her life was in the United States, where she remarried and gave birth to his half-brother. Warkana had not met his stepfather and his half-brother during his mother's two trips to Ethiopia. Thus, as the move to the United States grew closer, Warkana was anxious and worried about meeting his brother and stepfather for the first time. "I saw my mom six or seven years ago, [and] ... my brother, he is thirteen, you know ... He was born in America, I did not see him or my mother's husband (stepfather). I didn't see them [together] until when I get here and live with them".

Warkana's transnational family context reflected some of the disconcerting reality of family separation (Huang, Yeoh, \& Lam, 2008). Long-term separation can affect the parent-child relationship both during the time of separation and during reunification. In Warkana's situation, it was clear his pre-immigration ties to his mother (phone calls, financial remittances, and visits) facilitated their reconnecting as parent and child. In addition to re-establishing relationships, adolescent immigrants have the additional challenge of joining changed family structures as a parent remarries and/or has additional children. Warkana's discussion of his family situation in the United States_suggests that he was able to successfully adapt to changes within the family structure and re-establish relations with his parent and other family members. For example, Warkana expressed positive feelings about this reunification with his mother, stepfather, and half-brother: "Your family is your heart, and if you live with family, you [have] peace and happiness.”

\section{Educational Background}

Warkana came to the United States having completed nearly 10 years of education. He attended elementary and secondary school both in Tigray and in Addis Ababa and left the country in the 10th grade. His mother's remittances paid his tuition and fees for elementary and secondary education in Ethiopia. He attended school for 8 or 9 hours a day, usually "from 8 am until 5 pm” with a lunch break at home for 40 minutes. His schools were overcrowded and had limited resources, yet despite these limitations, Wankana felt he had "good teachers". Warkana received a bilingual education in Ethiopia, where the official language of instruction was Amharic and English was taught as a second language. Warkana reported having learned English as a foreign language although he had not had much opportunity to speak the language.

Once in the United States, Warkana's mother made the decision to enroll him a new pilot school specifically for immigrant students. As Warkana recalled, "My mom said the school was small and nice”. His school, Lake Ridge International High School (LRIHS), was small, with approximately 200 students compared to the average school size of around 1200 to 1800 students for most comprehensive high schools in the district. LRIHS opened in 2003 as a pilot school for the district's adolescent English language learners (ELLs). The school was modeled after New York City's international high schools for immigrant students (e.g., Bronx International and Long Island International), which began in the 1990s. As was typical of international schools, LRIHS had small classes, with an average class size of $10-12$, and qualified, hand-picked faculty who were also involved in school governance. The faculty organized field trips and cultural orientation activities to support their students' acculturation and engagement. 
LRIHS provided a high school curriculum that prepared students to meet the state's academic standards in English language arts, mathematics, and science at the same time they were developing English proficiency. Students were required to complete high school-level math, science, and history classes, with options for foreign language (Advanced Placement Spanish and French for French Speakers). Students were expected to meet and surpass the state learning standards as measured by a high school graduation test. In addition, they were required to complete a year-long course designed to build students' test-taking skills and familiarize them with the high-stakes graduation test. Teachers were required to differentiate instruction using sheltered English instruction and to provide language support for students.

Warkana was an honor roll student, with straight A's, and was well liked by his teachers at LRIHS. He identified language arts as the most difficult aspect of school in America. Yet Warkana viewed English as key to success in American school and in the larger society, and despite the presence of his best friend in many of his classes, Warkana made an extra effort to use only English in the classroom.

Mathematics was one area in which Warkana expressed some degree of confidence. As he explained, "Math is good, you know ... Math is easy for me because I know math.” In fact, he felt that the math in his previous school had been much more challenging than in his school in the United States:

We just learn hard over there ... We take hard classes, highlevel math. When I was 10th grade over there, I use to learn logarithms, but over here ... 12th grader learns logarithms ... Like when you are in 7th grade [there], you learn what you learn in $8^{\text {th }}$ grade or 9 th grade here or something.

However, like many students from developing countries, Warkana's experiences with advanced mathematics had not prepared him for the scientific calculators and other technology used in his math and science classroom in the United States. Warkana expressed frustration with the technology required in his math and science classes: "I had many, many question [about] homework because [the] calculator is hard. I just have to go to class early and talk to my teacher."

Warkana's persistence and efforts were recognized by his teachers. For example, Warkana had been encouraged by Mr. Cruz, his pre-calculus teacher, to attend a mathematics-focused college preparation summer program at an Ivy League university. Mr. Cruz helped him through every stage of the process, from completing the application and gathering recommendations to visiting the site of the summer program so that he would be familiar with its location. In describing his relationship with his teachers at LRIHS, Warkana stressed their caring, explaining that "student and teacher are like mom and child ... I feel the teacher care for student like that."

Warkana's educational background was a notable factor in his resiliency. His transition to U.S. schools was made easier in many ways by the academic resources he brought with him. These resources included native language literacy, strong preparation in mathematics and basic science, and some experience with English as foreign language. In addition to these resources, he was also motivated to learn, with concrete academic goals connected to college attendance. Research has long associated individual affective motivation with success in second-language learning (Beykont, 2002; Cummins, 2000; Lucas, 1997; Short \& Fitzsimmons, 2007).

Warkana also benefited from a supportive school context due in large part to caring teachers who set high expectations, provided support, and fostered students' potential. His teachers seemed to possess what Noddings (1984) refers to as an "ethic of caring." Teachers with an ethic of caring attend to the needs, motivations, and perspectives of their students. They create safe and caring learning communities, set high expectations, place rigorous demands on students, and provide support systems for meeting those high expectations (Delpit, 1998; Hersi, 2011; Nieto, 2000). Generally, an "ethic of caring” speaks to the level of concern and commitment teachers have for their students as persons and learners (Beykont, 2002). Clearly, by describing teachers and students as being "like mom and child," Warkana was highlighting the supportive and caring nature of his relationship with his teachers.

\section{Implications}

Although all African immigrant youth experience the stress and risk associated with migration, very little attention has been given to their resiliency. This study contributes to much-needed research highlighting the heterogeneity of African immigrant youth and the complex factors that contribute to their social and academic success in the United States. It demonstrates that Warkana's success as a resilient student was due primarily to his family support and the support and engagement he received in school.

Warkana's family was oriented toward life in the United States. His social network included family members and friends who were knowledgeable about schools in the United States. His family held clear and high expectations for his education. His mother stressed academic success in school and discussed college plans, often encouraging him to think about his future. For Warkana, there was a clear link between success in high school, college attendance, and future economic and career opportunities in the United States. "I want to go to college to maybe study engineering or become a doctor”, he announced. In addition to high expectations, he received substantial support from his family, including payments for extra tutoring classes, meeting with teachers, monitoring school progress, and encouraging him to take advantage of after-school programs in the school. Warkana's family was very involved in his education.

As a special school designed to serve the needs of immigrant students, LRIHS was in many ways particularly positioned to serve the needs of students like Warkana. LRIHS had a rigorous college preparatory curriculum that stressed mathematics and science, highly qualified teachers with many years of experience teaching in bilingual programs, and small classroom sizes. Moreover, the school offered students tangible and material support in the form of tutoring programs, internships, and summer programs. After-school tutoring programs and summer enrichment programs such as the mathematics camp that Warkana attended were critically important to the students, providing them with homework help, orientation to technology, and information about college access.

In addition to such tangible support, Warkana received emotional support from his teachers. This emotional support was characterized by a sense of caring and connection and served to keep Warkana engaged as he encountered academic and social challenges. Moreover, Warkana’s teachers set high expectations and created opportunities in school for building social networks. The findings suggest that it is essential that teachers carefully consider and understand immigrant students' backgrounds and their social and academic needs and strengths. Thus schools 
should recruit teachers with a disposition toward caring (Nieto, 2000) and provide professional development to foster their capacity to serve as cultural brokers (Beykont, 2002).

Although positive and caring relationships with teachers were an essential factor in Warkana's academic success, the study also found that his complex family relationships were critical to his school success. Warkana had experienced prolonged family separation as a result of immigration before being reunited with family members. His family situation and circumstances affected the types of support he had at home. Given the positive outcome of his family reunification, Warkana benefited from the love, encouragement, advice, and assistance he received from his family as he navigated his school context. This research upports earlier findings that, given the importance of family support in students' resiliency, educators need to understand students' family contexts, work to connect families to the school community, and provide resources to students and families who might be in stress (Bigalow, 2008; Hersi, 2011, Kibour, 2001; Portes, 1996).

As recommended by Beykont (2002), Fonor (2005), and Nieto (2000), even schools without the additional resources available to LRIHS can support students through collaborative and community partnerships that marshal resources for their families. This research suggests that schools, in addition to providing qualified and caring teachers, should recruit school counselors and social workers to address the socio-emotional needs of adolescents and families in stress. These professionals can provide specific support programs for youth who might be in conflict with a parent or might be experiencing stress associated with migration. Like the faculty and staff at Warkana's school, teachers and social workers can also assist and connect student and families to such community resources as job training, instruction in English as a second language, and social and psychological services.

\section{Conclusion}

Immigration today is largely transnational, where individuals forge and maintain ties between their country of origin and the countries in which they settle. Understanding the transnational the experiences of students like Warkana offers insight into the ways African immigrant youth draw on family and social resources to successfully negotiate social and academic barriers and become academically resilient.

\section{Acknowledgements}

I would like to thank my colleagues at Loyola and the editors and reviewers. The constructive feedback was extremely valuable.

\section{REFERENCES}

Arthur, J. A. (2000). Invisible sojourners: The African immi grant diaspora in the United States. Westport, CT: Praeger.

Beykont, Z. F. (Ed.) (2002). The power of culture: Teaching across language difference. Boston: Harvard Education Publishing Group.

Bigalow, M. (2008). Somali adolescents' negotiation of religious and racial bias in and out of school. Theory into Practice, 47, 27-34. doi:10.1080/00405840701764706

Boss, P. (1999). Ambiguous loss. Cambridge, MA: Harvard University Press.

Bryceson, D., \& U. Vuorela. (2002). 'Transnational families in the twenty-first century. In D. Bryceson \& U. Vuorela (Eds.), The transnational family: New European frontiers and global networks. Oxford: Berg.

Cummins, J. (2000). Language, power and pedagogy. Clevedon: Multi- lingual Matters.

Delpit, L. (1998). Other people's children: Cultural conflict in the classroom. New York: New Press.

Dreby, J. (2009). Gender and transnational gossip. Qualitative Sociology, 32, 33-52. doi:10.1007/s11133-008-9117-X

Elmelech, Y., McCaskie, K., Lennon, M. C., \& Lu, H. (2002). Children of immigrants: A statistical profile. New York: National Center for Children in Poverty.

Falicov, C. J. (2005). Ambiguous loss: Risk and resilience in Latino immigrant families. In M. M. Suárez-Orozco, C. Suárez-Orozco, \& D. B. Qin-Hillard (Eds.), The new immigration: An interdisciplinary reader. New York: Taylor and Francis.

Foner, N. (2005). The immigrant family: Cultural legacies and cultural changes. In M. M. Suárez-Orozco, C. Suárez-Orozco, \& D. B. Qin-Hillard (Eds.), The new immigration: An interdisciplinary reader. New York: Taylor and Francis.

Getahun, S. A. (2007). The history of Ethiopian immigration in the United States in the twentieth century, 1900-2000: Patterns of migration, survival, and adjustment. New York: Scholarly Publications LLC.

Gibson, M. (1988). Accommodation without assimilation: Sikh immigrants in an American high school. Ithaca, NY: Cornell University Press.

Glick-Schiller, N. (1997). The situation of transnational studies. Identities, 4, 155-166. doi:10.1080/1070289X.1997.9962587

Harris, J. E. (1993). The global dimension of the African diaspora (2nd ed.). Washington DC: Howard University Press.

Hersi, A. A. (2011). Immigration and resiliency: Unpacking the experiences of high school students from Cape Verde and Ethiopia. Journal of Intercultural Education, 22, 189-202.

Huang, S., Yeon, B., \& Lam, T. (2005). Asian transnational families in transition: The limitations of simultaneity. International Migration, 46, 3-12. doi:10.1111/j.1468-2435.2008.00469.x

Human Rights Watch. (2008). Ethiopia: Events in 2008. URL (last checked 26 June 2008). http://www.hrw.org/en/node/79222

Kamaya, H. A. (1996). African immigrants in the United States: The challenge for research and practice. Social Forces, 42, 154-165.

Kivisto, P. (2001). Theorizing transnational immigration: A critical review of current efforts. Ethnicity and Racial Studies, 24, 549-577. doi:10.1080/01419870120049789

Kibour, Y. (2001). Ethiopian immigrants' racial identity attitudes and depression symptomatology: An exploratory study. Cultural Diversity and Ethnic Minority Psychology, 7, 47-59. doi:10.1037/1099-9809.7.1.47

Lee, J., \& Bean, F. D. (2004). America's changing color lines: Immigration, race/ethnicity, and multiracial identification. Annual Review of Sociology, 30, 221-242.

doi:10.1146/annurev.soc.30.012703.110519

Lucas, T. (1997). Into, through, and beyond secondary schools: Critical transitions for immigrant youth. Arlington, VA: Center for Applied Linguistics.

Matteo Terrazas, A. (2007). Beyond regional circularity: The emergence of an Ethiopian diaspora. Migration Information Source, retrieved 20 August 2011.

Nieto, S. (2000). Affirming diversity: The sociopolitical context of multicultural education (3rd ed.). New York: Longman.

Nodding, N. (1984). Caring. Berkeley, CA: University of California Press.

Perez, W., Espinoza, R., Ramos, K., Coronado, H., \& Cortes, R. (2009). Academic resilience among undocumented Latino students. Hispanic Journal of Behavioral Science, 31, 149-189. doi: $10.1177 / 0739986309333020$

Portes, A. (1996). The new second generation. New York: Sage.

Portes, A., \& Rumbaut, R. (2001). Legacies: The story of the immigrant second generation. Berkeley, CA: University of California Press.

Portes, A., \& Zhou, M. (1993). Segmented assimilation and its variants. Annuals of the American Association of Political and Social Sciences, 530, 74-96. doi:10.1177/0002716293530001006

Reyes, O., \& Jason, L. (1993). Pilot study examining factorsassociated with academic success for Hispanic high school students. Journal of Youth and Adolescence, 22, 57-71. doi:10.1007/BF01537904

Reimers, D. M. (2005). Other immigrants: The global origins of the 


\section{A. A. HERSI}

American people. New York: New York University Press.

Rong, X. L., \& Brown, F. (2002). Immigration and urban education in the new millennium: The diversity and the challenges. Education and Urban Society, 34, 123-133. doi:10.1177/0013124502034002001

Schmidley, D. (2001). Profile of the foreign-born population in the United States: 2000. Washington DC: US Census Bureau.

Short, D., \& Boyson, B. A. (2004). Creating access: Language and academic programs for secondary school newcomers. Washington DC: Center for Applied Linguistics.

Short, D., \& Fitzsimmons, S. (2007). Double the work: Challenges and solutions to acquiring language and academic literacy for adolescent English language learners. New York: Carnegie Corporation.

Suárez-Orozco, C., \& Suárez-Orozco, M. (2001). Children of immigration. Cambridge, MA: Harvard University Press.

Suárez-Orozco, C., Todorova, I., \& Louie, J. (2002). "Making up for lost time": The experience of separation and reunification among immigrant families. Family Process, 41, 625-643.

doi:10.1111/j.1545-5300.2002.00625.x

Suárez-Orozco, C., Bang, H. J., \& Kim, H. Y. (2011). "I felt like my heart was staying behind”: Psychological implications of immigrant family separations and reunifications. Journal of Adolescent Research, 26, 22-257.

US Census. (2010). Census 2010. Washington DC: US Census Bureau. US Census. (2006). Census community survey. Washington DC: US Census Bureau.

Wang, M. C., Haertel, G. D., \& Walberg, H. J. (1993). Towards a knowledge base for school learning. Review of Educational Research, 63, 249-294.

Waxman, H. C., Gray, J. P., \& Padron, Y. N. (2003). Review of research on educational resilience (11). Santa Cruz: Center for Research on Education Diversity and Excellence, University of California. 